Housing Movements and Participation in Institutional Spaces | 128

VALESCA LIMA'

\title{
Housing Movements and Participation in Institutional Spaces ${ }^{2}$
}

\section{Introduction: Underlying Issues for Social Inequality}

When assuming power in 2003, Lula promised the inclusion of civil society and social movements in the policy-making sphere. It was partially addressed through the creation of councils and other actions to protect cultural and women's rights, for example. However, in Rousseff s government, civil society and social movements continued to be excluded from the higher spheres of power and were not properly listened to. They have demonstrated a great interest in participating in and collaborating with the process of formulating public policy, as civil society members have a high attendance on forums and put forward a high number of motions on those topics. However, it is possible to observe a disconnect between the Workers' Party leadership and its grassroots. Consequently, since 2012-2013, Brazil has entered into a political crisis, as well as an economic one, without precedent in the history of the country, as the population is angered at revelations of widespread corruption, along with rising inflation and unemployment (Perry, 2016; Melo, 2016).

Brazil became a regional power in Latin America and a strong economic power in the 21 st century. During this time, the predominant practices of patrimonialism and the oligarchical model of administration marginalised popular classes politically and economically. Even considering the relative improvements in the level of human

\footnotetext{
1 VALESCA LIMA is a postdoctoral research fellow at University College Dublin specialising in governance, participatory democracy, housing policies, social movements and Latin America politics.

2 This article was originally published in http://www.alternautas.net/blog/2018/8/7/housingmovements-and-participation-in-institutional-spaces on August $7^{\text {th }}, 2018$.
} 
development in the region, particularly in Brazil, poverty and socio-economic inequalities continue to be widespread (ECLAC, 2014). High levels of corruption, the politicisation of the courts, and political coercion have a strong role in protecting the interests of the traditional elites in the context of neoliberal domination in Brazil and more broadly in Latin America (Dagnino, 2007).

The states in the north and in the north-eastern regions of the country, such as Alagoas and Roraima, are more likely to see the poor and the less fortunate mobilised in favour of local politicians, extending this authority to traditional families that dominate the local political scene. In some states in the north-east, families that currently dominate the political sphere are the same ones that governed the state before the transition to democracy. These families continue to control the state's legislature and local media enterprises (Power, 2016; Lewin, 2014). The return to democracy in Brazil in 1985 marked not only a significant political transition, but also the ascendancy of civil society organisations and social movements. The new 1988 constitution introduced a wide range of participatory mechanisms, including management councils in different areas (education, health, housing, and social security) and new responsibilities for local governments. Decentralised reforms have had a direct impact on enhancing the capabilities of civil society and have provided social movements with meaningful opportunities for shaping local development (Heller, 2012).

Brazil faces problems that are common in developing countries, such as high poverty levels, low living standards, shantytowns, high crime rates and deep social inequality (HDR report, 2015). However, among middle-income countries, Brazil's inequality rates have been falling since the 1990s, with the associated impact of reducing extreme poverty (National Household Sample Survey - PNAD, 2013). By promoting the economic emancipation of the poor and improving living conditions for the middle class, economic stability was achieved for a certain period and the Workers' Party obtained legitimacy and electoral support, as shown by its electoral success in winning four consecutive presidential elections. 
Housing Movements and Participation in Institutional Spaces | 130

A variety of social programs were created to tackle those social issues, but addressing these issues properly has proved to be difficult for two reasons. Firstly, social problems are deeply embedded in Brazilian society and current social investment in these areas has been selective. Secondly, despite the Workers' Party's social project and their success in some areas over the years (e.g. income distribution programs, such as "Bolsa-familia"), those social programs focused on the effects, not on the causes of social inequalities.

The rest of this article is organized as follows: In section 2, I discuss the process of inclusion of new voices from civil society, with the creation of policy councils, and I discuss, in particular, key outcomes of the processes of inclusion of social groups that had been systematically excluded from spheres of decision-making. In section 3, I examine the introduction of popular participation in democratic institutions, taking the creation and implementation of housing councils as a reference. In section 4, I briefly analyse the challenges of expanding citizen participation in the area housing policy-making. Finally, section 5 concludes and offers some suggestions for future research.

\section{The Inclusion of New Voices}

Over the last 30 years, social movements and civil society organisations have taken advantage of a series of political opportunities made available by the new democratic regime since the promulgation of the 1988 Constitution. Once democracy began to be consolidated during the 1990s, one democratic innovation to promote popular participation stood out among participatory experiences: Participatory Budgeting. Municipalities where the Workers' Party had a mayor were the first to introduce this model of citizen participation. Participatory practices promote significant advances in city management. They are said to stimulate the inclusion of the poor in decisions on public spending, to allow more social control over public investment, to encourage active citizens and to break typically clientelistic relations (Fedozzi, 2016; Sousa Santos, 2007; Cornwall, 2008). The practices of Participatory Budgeting have been internationally acclaimed and implemented in many Brazilian cities, including large 
urban areas, such as Porto Alegre, São Paulo and Recife and around the world (Chicago and Utrecht, for example).

Despite some variation in design and implementation from one municipality to another, the baseline institutional features include the creation of local assemblies composed of ordinary citizens that decide and prioritise demands for their communities. In turn, these demands are voted on by a large assembly and then included in the city budget (Baiocchi et al., 2008). Since its creation, Participatory Budgeting has undergone great expansion, initially in Brazil and later on an international scale. According to Ribeiro and Grazia (2013) the number of municipalities implementing Participatory Budgeting went from 10 (1993-1996) to 355 (2008-2012). In more recent studies, Spada (2012) shows that, after the expansion in previous years, these numbers have consistently declined, reflecting political and economic changes that are possibly connected with the weakening of the Workers' Party and the economic crisis affecting municipalities, which has affected the cities' capacity to invest in Participatory Budgeting events.

Local governments in particular have committed to these democratic innovations and have succeeded in many cases. One of the best-known accomplishments has been the increase and strengthening of participatory institutions, both in terms of numbers and scope, represented by the large number of councils and conferences that have taken place over the years. This process started just after Collor de Mello's (president from 1990-1992) tenure, but it only saw significant improvements during Lula's term. During this period, the volume of institutional investments, government resources and people involved in participatory democracy practices significantly improved.

It is possible to observe from the data released from a joint research by Instituto Pólis and Instituto de Estudos Socioeconômicos Institute (INESC) on democratic governance in contemporary Brazil that, at national level, more than one third of the councils were created during the Workers' Party administration (see Figure 1). The second highest peak happened just after the new 1988 constitution, in a period that covers three presidencies (Sarney, Collor and Itamar). 
Most of the areas mapped are prior to the administration of President Fernando Henrique Cardoso. Some of those councils were created in non-democratic periods, which appear to be a contradiction. A closer look at the creation date of those councils suggests that most of them were created before the beginning of military rule in 1964, such the National Council of Culture, which was created in 1938, but was maintained and restructured in line with the prevailing ideology of the military government. Most of the councils came into existence during the democratisation process.

In the year of the promulgation of the 1988 Constitution, and the following two years, seven councils were created. Nevertheless, the highest number of national councils was created in 2003 with eight new councils in total. However, in contrast with the participatory models implemented systematically during the Workers' Party administration, until early 2000's such councils had no participatory format. They existed as in a traditional institutional model, without the mechanisms that guarantee participation of ordinary citizens (i.e. members of the council were not elected but rather appointed by government).

Councils are distinguished by their goals and ways of working. A policy council is a council that contributes to the formulation of public policies for a given area, such as policies on health, education, welfare, urban planning, and rural development etc. The majority of the mapped councils are policy councils, a total of 40, as shown in Figure 1. 


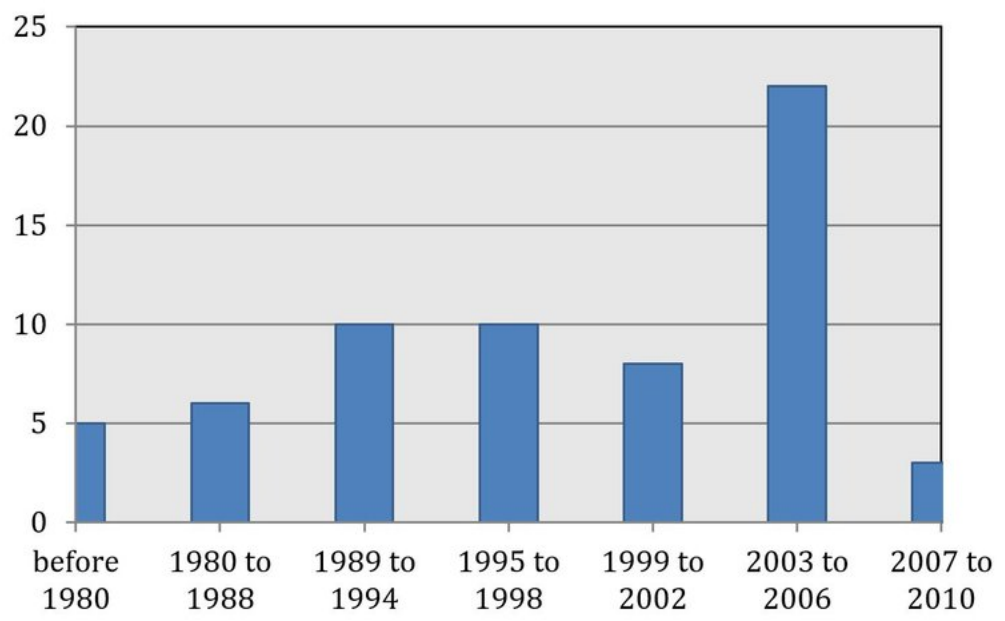

Figure 1: National councils created by year (Source: Dagnino and Teixeira, 2014)

Rights councils are councils that deal with the rights of a particular population, generally marginalized groups that are supposed to need specific policies. Of course, all councils deal directly with the issue of social rights (Dagnino and Teixeira, 2014). However, in this case, the right of the population in question is the focus of the council. In the INESC-PÓLIS research, 11 councils are of this type. Examples of this kind of council are the National Council for the Rights of the Elderly and the National Council for Fighting Discrimination and Promoting LGBT Rights.

Those councils reflect new thematic areas and the inclusion of new voices in spaces that have never been to social sectors before. The CONSEA (Conselho Nacional de Segurança Alimentar or Food Securiry Council) was created just after Lula's inauguration in 2003, as a strategic part of his nationwide program against extreme poverty - Zero Hunger (Fome Zero). The CONSEA gives representation to a multiplicity of social sectors-connected to, for instance, human rights, women, blacks, indigenous peoples, quilombola communities, agrarian reform, and several others - aiming for increased inclusion by expanding representation and creating spaces for policy decision-making (Dagnino and Teixeira, 2014). As a council, the CONSEA deals issues related to family farming, school food projects, and the 
creation of a commission to unite civil society and government in order to formulate public policies in the area.

A good example of the expansion of policy themes and the inclusion of new voices has occurred in cultural areas, which have received a boost with the creation of the National Council of Cultural Policies. This latest initiative came about as a result of demands from popular artists and cultural producers involved in Lula's electoral campaign. Before that, cultural policies were characterised by an unequal and unclear funding distribution (Souza, 2008).

Civil society and social movements have not been limited to only exerting pressure on the government from the point of view of institutional change. Their mobilisation has brought them beyond these spaces. As an example, the creation and implementation of the Maria da Penha law can be cited, which increased punishment for violence against women, a long-time demand from NGOs and groups fighting for women's rights. In the same way, groups defending racial equality were included in participatory processes to formulate policies for Afro-Brazilians, including quotas in third level institutions and more rigid laws to curb racism.

The key outcome of those processes was the inclusion of social groups that had been systematically excluded from the sphere of decision. Their inclusion did not come as a gift; it came as a result of the strong pressure exerted by the public sector on the Workers' Party administration but also as a result of the party's own social agenda. The engagement of these social groups in new policy-making venues helped to broaden relevant themes and extend the right of participation and social control to those groups. This social control, nevertheless, comes with limitations. In the next section, I examine how the inclusion of social movements in spaces of decisionmaking has taken place, especially in the social housing area.

\section{The Introduction of Popular Participation in Democratic Institutions}

In order to understand the impact of councils at the local level, it is important to clarify the process that has promoted the integration of social movements in 


\section{5 | AlternautAS 5 (1) - JULY 2018}

democratic institutions. Since the inclusion of mechanisms of participatory democracy in the 1988 Constitution, social movement organisations have slowly been included in the formulation and implementation of social policies. This process of institutionalisation was considered by many as one of the main successes achieved by civil society and social movements at the time. These participatory spaces, however, were not implemented immediately, since legislation demanded complementary laws to regulate participatory practices. In that sense, it was down to the political will of the incumbent in power if this legislation was to be implemented or not.

The 1988 Constitution created municipal-level councils for healthcare, education, social assistance and housing, amongst other areas. These participatory institutions normally designate half of the seats for civil society and the other half to government officials. This allocation of seats varies from council to council, according to internal regulations and local contexts. Another difference is in the allocation of funds: municipalities that have established specific municipal funds for social policies generally decide where and how funds will be used - as is the case with municipalities with specific funding for housing.

Within this scenario, 2012 data from IBGE (Brazilian Institute of Geography and Statistics) shows that councils for municipal health, welfare and children's rights exist and are fully operational in $99 \%$ of Brazilian cities. Councils for the elderly, culture and the environment are present in over $50 \%$ of Brazilian municipalities, which demonstrates the scope and potential of these instances of participation. Municipal housing councils are present in $76 \%$ of Brazilian municipalities. In some cases, the so-called "municipal council of the city" includes social housing issues (IBGE, 2012).

In the housing area, the Constitution stipulates that the municipality is the entity at the local level responsible for implementing housing policies. For this reason, municipal housing councils have an important role in defining housing policies locally. In many municipalities, the council in charge of housing policies is the municipal council of cities (Conselho Municipal das Cidades), following the model of Ministry of Cities and the National Council of Cities and covering areas of urban 
Housing Movements and Participation in Institutional Spaces | 136

public policies, including housing. Each municipality elaborates its own local housing council plans, determining mechanisms to establish rules for the composition of the council, frequency of meetings, members' duties and the general scope of the council decision-making authority. Both government and society are responsible for drawing up an agenda for social housing. However, government plans to tackle the housing issue often clash with demands emanating from housing movements. I will therefore now consider social movements for housing rights that have been influential in defining the change in pro-poor social housing policies.

Taking housing councils as an example, social movements for housing were important for the inclusion of housing rights in the Constitution and they influenced the creation of the national housing council and municipal housing councils. Housing movements are responsible for pressing governments to implement the national social housing policy. For the most part, social movements connected to the housing issue in Brazil focus their agenda on social housing provision and land redistribution. Other issues, such as security of tenure and the urbanisation of shanty towns are also their concern. Entities connected to social mobilisation for housing rights range from small neighbourhood associations to national level organisations, (Donaghy, 2013) including NGOs—such as the "Instituto Sertão" and the "Ação Moradia" - and social movements, such as the National Union for Popular Housing (Uniāo Nacional por Moradia Popular).

Social movements connected to housing rights grew in strength from the 1980 s onwards, during the process of democratisation, especially in the 1990s after the economic crisis. Despite the concentration of bigger social movements for housing in Rio and Sao Paulo, social groups from other parts of the country were also demanding housing. These groups also started to re-organise themselves following the creation of housing councils, which gave a boost to the social movements in the area, after a period of strong NGO-isation. While groups based in urban areas are more preoccupied with the urbanisation of favelas and the reallocation of families to new house units, social movements based in rural areas have different demands, which include programs to provide construction material, plots of land and credit strategies (Donaghy, 2013). 
Land and building occupations are central tactics used by social movements to call attention to their cause. Some movements have used them as their main tactic and have become stronger after conducting many land and building occupations in different cities around the country, such as the Landless Movement (Movimento dos Sem Terra) and the Homeless Workers' Movement (Movimento dos Trabalhadores Sem Teto) in São Paulo. Police violence is usually extreme against these groups. Although the position of Lula's government came closer to that of popular housing demands during his eight-year term, the current administration does not maintain the same good relations with social movements. While public resources have been allocated to housing in the urban centres, under the current administration, rural areas have had the lowest investment over the last 20 years, according to the National Institute of Colonization and Agrarian Reform (Instituto Nacional de Colonização e Reforma Agrária - INCRA).

Urban social movements for housing rights had been strong supporters of President Lula da Silva's candidacy since the first direct election in 1990. When he eventually came to power as President in 2003, social movements for housing were strong enough to pressure the government into creating the National Council of Cities (ConCidades-Conselho Nacional das Cidades), where housing policies were discussed in conjunction with other urban policies. In 2005, new legislation-the Social Housing National System (Sistema National de Habitação Social)—was created, in which municipalities seeking funding could obtain membership in order to obtain access to federal funds.

The National Social Housing System was created to implement innovative and democratic procedures to promote public participation in decision-making. It seeks to encourage municipal governments to play a more active role. In order to obtain funding from this program, municipalities must set up a council (at the state or local level) and contribute to $10-20 \%$ of the housing investment-depending on the region. This system is an instrument that provides housing to those who cannot have access to credit without a subsidy from government. This program targets families earning less than three times the minimum monthly wage (Valença and Bonates, 
Housing Movements and Participation in Institutional Spaces | 138

2010). Despite this government intervention in social housing, the literature has criticized this model, as it usually benefits certain social groups with a better income.

\section{Social Housing and the Limits of Participatory Institutions}

Quantitatively, there has been a significant increase in participatory spaces in previous years (Dagnino, 2005; Dagnino and Teixeira, 2014). However, it is crucial to consider the quality of this participation and the challenges posed to social movements. Housing councils were created with a view to including the voices of those most affected by housing issues. However, controversy continues as to how open those spaces are and whether the popular demands are being listened to and dealt with.

Although included in the UN charter and in Brazilian legislation as a basic human right, housing continues to be a social good that is inaccessible to a significant part of the population. Movements for social housing are comprised of a vast number of diverse organisations, especially in medium and large cities. These movements have been able to mobilise a large number of people and sometimes have different demands. Some will demand homes for their members, while others exert pressure on the government for public investment in the sector and changes in housing legislation (Boito and Berring, 2014). These social movements are inserted in a model of development that is said to share decision-making power with popular sectors.

As a political opportunity structure, municipal housing councils permit the inclusion of new voices, but this is limited by the very institutions that open up this structure. In previous studies, housing movements have been studied in the context of participatory democracy by measuring whether they are successful and if their participation generates more social housing units. Those studies found that, since the introduction of participatory experiences in housing policies, there are more housing projects and there is more investment in housing in general. There is greater availability of funding, security of tenure, urbanisation of informal settlements, title possession, etc., and it is clear this "success" is connected to the existence of a council (Touchton \& Wampler, 2014). Donaghy (2013) found in particular that 
municipalities that have an active housing council have a tendency to implement a wider variety of social housing programs, and that participatory democracy has an impact on policy outcomes.

The creation of the Ministry of Cities in 2005 reflected decades of struggle by the National Urban Reform Movement to change federal, state and municipal institutions. A key component of these struggles was the focus on the creation of formal arenas for civil society participation (Abers et al. 2014, Saule and Uzzo, 2012). The promotion of participatory democracy was one of the main social compromises of the Workers' Party before it came to power. Looking at the numbers, as participatory spaces were created, people were mobilised and new public policies and new voices were included in this process. However, those newly-created entities did not have the impact they were expected to, especially for social movements and Workers' Party activists. Instead of spaces for debate and new proposals, in many cases they turned out to be spaces for dialogue and listening to public demands (Dagnino and Teixeira, 2014). A good example to support this claim is that $58 \%$ of the councils are only consultative (INESC and Pólis, 2011), meaning that the deliberations coming from the council do not have to be followed by government.

Advances in the creation of new government agencies to promote popular participation were not aligned with concrete changes in the way those agencies are functioning. New policy areas were included and attention was focused on new social themes. However, the inclusion of civil society in those spaces and the acknowledgment of their demands by the government were not followed by action to promote change in a substantial way. As argued by Abers et al. (2014), despite the creation of a great number of participatory institutions over the years, changing the notion of popular, the Lula administration did not have a centralized and uniform project that aimed at institutionalizing participatory policies. Participatory capacities already existed, and the new routines that seem to have proliferated during the Workers' Party administration should be understood as a result of the maturity and complexity of specific Brazilian social movements, combined with opportunities for institutional participation. 
Housing Movements and Participation in Institutional Spaces | 140

\section{Conclusion}

An analysis of the political and social context of Brazil highlights the relationship between citizens and the state. The inclusion of citizens-represented by social movements - in spaces of decision-making, marked a period of intense dialogue and negotiation, which led to legislation that guarantees popular participation in the implementation of social policies. The challenge for social movements has been to keep the channels of popular participation open and to try to convert social innovation into meaningful public policies. Rather than merely including more citizens in the public sphere, the challenge here is to create a more inclusive public sphere by promoting citizenship, defending accountability and avoiding reclientisation.

During the Workers' Party, an intense process of institutional innovation took place. However, since 2016, with the impeachment of President Dilma Rousseff by means of a parliamentary manoeuvre, participatory policies have been systematically dismantled. While a decline in the relationship between social movements and government had been already observed during Rousseff s administration (Abers et al., 2014), the recent cuts in social spending has threatened the function of national and municipal councils. If a decade ago Brazilian democratic innovations attracted academic attention and gave hope for building stronger democracies around the world, currently, participatory spaces, such as council and national conferences, are under risk of being disarticulated by conservative political agendas.

If one achievement was the expansion of participatory spaces to new thematic areas to promote meaningful changes in public policy-making, the challenge to academics is to understand what is at stake for social movements under the right-wing government, which has consistently dismissed the system of popular participation via institutional politics. More than ever, the quality and modes of participation in these spaces deserve a more in-depth analysis. In other words, the way decision-making power is shared with social movement organisations is central to the analysis of participatory democracy. The effectiveness of participation cannot be defined only in 
quantitative terms, but it can be demarcated by the way social movements have been able to influence change.

\section{References}

Abers, R., Serafim, L., Tatagiba, L. (2014), "Repertoires of state-society interaction in a heterogeneous state: the Lula Era experience”. Dados 57, 325-357.

Baiocchi, G., Heller, P., Silva, M. K. (2008). "Making Space for Civil Society: Institutional Reforms and Local Democracy in Brazil”. Social Forces 86, 911-936.

Barbosa, A. de F. (2012). Brasil Real: a desigualdade para além dos indicadores (Brasil Real: a desigualdade para além dos indicadores).

Bohn, S. (2011). "Policy and Vote in Brazil: Bolsa Família and the Shifts in Lula's Electoral Base”. Latin American Research Review 46.

Boito, A., Berringer, T. (2014), "Social Classes, Neodevelopmentalism, and Brazilian Foreign Policy under Presidents Lula and Dilma”. Latin American Perspectives 41, 94-109.

Cornwall, A. (2008). "Deliberating Democracy: Scenes from a Brazilian Municipal Health Council”. Politics Society 36, 508-531.

Dagnino, E. (2007). "Dimensions of Citizenship in Contemporary Brazil”. Fordham L. Rev. $75,2469$.

Dagnino, E. (2005). Meanings of citizenship in Latin America. Institute of Development Studies, University of Sussex.

Dagnino, E., Teixeira, A. C. (2014). "The Participation of Civil Society in Lula's Government”. Journal of Politics in Latin America 6.

Donaghy, M. M. (2013). Civil Society and Participatory Governance: Municipal councils and social housing programs in Brazil. Routledge, New York, NY.

ECLAC (2014). "Compacts for Equality: Towards a Sustainable Future" (Text). Economic Commission for Latin America and the Caribbean. 
Housing Movements and Participation in Institutional Spaces | 142

Fedozzi, L. (2016). "Orçamentos Participativos, Direito à Cidade e crise da democracia” [WWW Document]. Le Monde diplomatique. URL

http://www.diplomatique.org.br/acervo.php?id=3226 (accessed 7.22.16).

Hagopian, F. (1990). "Democracy by Undemocratic Means”? Elites, Political Pacts, and Regime Transition in Brazil. Comparative Political Studies 23, 147-170.

Heller, P. (2012). "Democracy, Participatory Politics and Development: Some Comparative Lessons from Brazil, India and South Africa”. Polity 44, 643-665.

(IBGE) Instituto Brasileiro de Geografia e Estatística (2015). Pesquisa de Informacoes Basicas Municipais: Perfil dos Municipios Brasileiros, Gestao Publica (MUNIC) 2012. Brazil.

Lewin, L. (2014). Politics and Parentela in Paraiba: A Case Study of Family-Based Oligarchy in Brazil. Princeton University Press.

Melo, M. A. (2016). "Crisis and Integrity in Brazil". Journal of Democracy 27, 50-65.

OECD (2015). Active with Brazil.

Perry, A. (2016). "Crisis in Brazil”. London Review of Books 15-22.

PNAD (2013). National Household Sample Survey (Survey). IBGE, Brasília, Brazil.

POLIS/INESC (2011). Arquitetura da participação no Brasil: avanços e desafios (The Architecture of Participation in Brazil: Advancements and Challenges).

Power, T. J. (2016). “The Brazilian Military Regime of 1964-1985: Legacies for Contemporary Democracy”. IBEROAMERICANA 16, 13-26.

Ribeiro, A.C.T., Grazia, G. (2003). Experiências de Orçamento Participativo no Brasil: periodo de 1997 a 2000 [Participatory Budgeting Experiences in Brazil: 1997-2000 period]. Sao Paulo.

Saule, N.J., Uzzo, K. (2009). “A trajetória da reforma urbana no Brasil Núcleo de Pesquisa em História”. URL http://base.d-p-h.info/pt/fiches/dph/fiche-dph-8583.html (accessed 7.10.18).

Souza, C. (2008). Partilha de Poder Decisório em Processos Participativos Nacionais (Sharing Decision Power in Participatory Processes). (Master's Dissertation in Political Science). University of Brasília, UnB., Brasília, Brazil.

Spada, P. (2015). Participatory Budgeting Census: 1989-2012. 
Touchton, M., Wampler, B. (2014). "Improving Social Well-Being Through New Democratic Institutions". Comparative Political Studies 47, 1442-1469.

Valença, M.M.; Bonates, M.F. (2010). "The trajectory of social housing policy in Brazil: From the National Housing Bank to the Ministry of the Cities". Habitat International 34, 165-173. 